\title{
EFFECTIVENESS OF INFLUENZA VACCINATION IN ELDERLY OUTPATIENTS IN SÃO PAULO CITY, BRAZIL
}

Eliana Battaggia GUTIERREZ(1), Ho Yeh LI(1), Ana Catarina De Seixas SANTOS(1) \& Marta Heloísa LOPES(1)

\begin{abstract}
SUMMARY
To investigate the effectiveness of the influenza vaccine in a population of elderly outpatients, we compared the occurrence and frequency of influenza like illness (ILI), respiratory illness and hospitalization in vaccinated and non-vaccinated subjects. All the outcomes were clinically defined. The two groups were similar with respect to demographics, health situation and habits. The influenza vaccine contributed to the protection of the elderly investigated, since the vaccinated subjects referred a significantly lower number of ILI than the non-vaccinated. There is a need for more studies about the effectiveness of the influenza vaccine in our country in elderly and other groups of our population.
\end{abstract}

KEYWORDS: Influenza; Influenza Vaccine; Elderly.

\section{INTRODUCTION}

Influenza is an acute respiratory illness characterized by fever, myalgia, cough and headache. The aetiologic agent is an Orthomyxovirus, and three serotypes, A, B and C, are known to cause human illness. The disease lasts, in median, for three days, but cough and malaise can persist for weeks. Complications of influenza include bronchitis and pneumonia, besides otitis media and exacerbation of chronic respiratory disease ${ }^{15}$.

The virus consists in an RNA core and a protein envelope. It has a marked capacity to mutate its external antigenic composition, thus escaping the host immune defenses. Minor changes in virus antigenic composition cause local epidemics. Pandemics arise when major changes in antigenic composition occur. Pandemics are thought to originate at the Far East, where humans, pigs and avian live in close proximity ${ }^{6,9}$.

Climate, humidity and life-style are other factors associated to the occurrence of the influenza.

The excessive morbidity and mortality, expressed as pneumonia, excessive hospitalization and death among elderly and patients with chronic medical conditions are described as the most serious result of influenza epidemics.

The World Health Organization leads a worldwide Program of Prevention of Influenza, through a network of laboratories that provides surveillance and identification of influenza virus isolates from different continents.
The Regional Group of Observation of Influenza (GROG) started its activities in 1995, in Brazil. Besides WHO, the GROG, now designated as "Grupo de Vigilância Epidemiológica da Gripe (VIGIGRIPE)" is responsible for the surveillance of the Influenza in Brazil. The number of specimens isolated and the viral identification is improving every year. In 1999 the VIGIGRIPE collected 1599 specimens and identificated 239 type $\mathrm{A}$ and 21 type B influenza virus ${ }^{16}$.

In order to formulate the vaccine, viruses from all over the world are evaluated and, in February for the northern hemisphere, and in September for the southern hemisphere, the WHO publishes which strains of Influenza virus will likely predominate in the next season.

The influenza vaccine is effective in elderly and patients with chronic medical conditions, as it has been demonstrated by different studies, many of them from the northern hemisphere ${ }^{2,11}$.

The aim of this study was to investigate the level of protection conferred by the influenza vaccine in elderly outpatients from the city of São Paulo, Brazil.

\section{SUBJECTS AND METHODS}

This retrospective study was held during the 2000 annual campaign of vaccination against influenza. Individuals 60 years or older who sought the Immunization Center, located at the "Hospital das Clínicas da Faculdade de Medicina da Universidade de São Paulo", in São Paulo city, for influenza vaccine, were enrolled. A questionnaire containing

Division of Infectious Diseases from the Hospital das Clínicas da Faculdade de Medicina da Universidade de São Paulo, SP, Brazil.

Correspondence to: Dra Eliana Battaggia Gutierrez, Rua Miranda Montenegro 162, 05412-020 São Paulo, SP, Brasil. email: elianabg@matrix.com.br 
information on demographics, health conditions such as diabetes mellitus, systemic arterial hypertension (sah), chronic obstructive pulmonary disease (copd), asthma, bronchitis, pulmonary emphysema, previous respiratory disease, hematological disease, neoplasm, therapeutic with corticosteroids, tobacco and alcohol use and influenza vaccination in 1999 was applied. The same two investigators applied all the questionnaires. All the answers were registered.

The primary outcomes measured refer to the comparative occurrence, in the previous 12 months, of influenza like illness (ILI), characterized as fever, cough, myalgia and headache, frequency of ILI, respiratory illness defined as any other disease than ILI compromising the respiratory system, hospitalization and hospitalization for respiratory diseases. All outcomes were clinically defined. No laboratory tests were applied to confirm reported episodes of ILI.

Statistical analysis: Subjects vaccinated against influenza in 1999 were compared with those non-vaccinated with respect to all variables described above. The Pearson $\chi^{2}$ and the t-test were used to assess differences in proportions and medians of discrete and continuous data.
A confidence level of $95 \%$, with $\mathrm{p}<0.05$ was considered statistically significant.

\section{RESULTS}

In this study 187 subjects were enrolled. Of these $70.1 \%$ (131) had received influenza vaccine in 1999 . The composition of the vaccine used in 1999 was A/Sydney/5/97(H2N3); A/New Caledonia/20/29(H1N1); B/Beijing/184/93.

The vaccinated and non-vaccinated subjects did not differ with respect to sex, age, presence of underlying diseases, tobacco and alcohol use (Table 1).The only significant difference was in the number of episodes of influenza like illness (ILI). The vaccinated subjects referred less episodes of ILI than the non-vaccinated ones (Table 2).

\section{DISCUSSION}

Our study focused on the association of vaccination against influenza and the occurrence and frequency of clinically defined influenza likeillnesses, respiratory diseases, use of antibiotics for any disease and for

Table 1

Demographic characteristics, chronic diseases and habits of the patients

\begin{tabular}{|c|c|c|c|c|}
\hline Characteristics & VAI* $131(70.1 \%)$ & Non-VAI $56(29.9 \%)$ & $\mathbf{n}$ & $\mathbf{p}$ \\
\hline Male sex & $30(42.9 \%)$ & $40(57.1 \%)$ & & 0.51 \\
\hline Age, median, y & $\mu=71.6$ & $\mu=66.4$ & & 0.67 \\
\hline Diabetes mellitus & $24(18.3 \%)$ & $15(26.8 \%)$ & $39(20.9 \%)$ & 0.19 \\
\hline Arterial hypertension & $67(51.1 \%)$ & $30(53.6 \%)$ & $97(51.9 \%)$ & 0.76 \\
\hline Copd*/asthma/ Bronchitis & $18(13.7 \%)$ & $6(10.7 \%)$ & $24(12.8 \%)$ & 0.57 \\
\hline Pulmonary emphysema & $6(4.6 \%)$ & $3(5.4 \%)$ & $9(4.8 \%)$ & 0.82 \\
\hline Previous pulmonary disease & $25(19.1 \%)$ & $6(10.7 \%)$ & $31(16.6 \%)$ & 0.15 \\
\hline Hematological disease & $6(4.6 \%)$ & $3(5.4 \%)$ & $9(4.8 \%)$ & 0.82 \\
\hline Corticosteroid use & $12(9.2 \%)$ & $2(3.6 \%)$ & $14(7.5 \%)$ & 0.18 \\
\hline Neoplasm & $7(5.3 \%)$ & $3(5.4 \%)$ & $10(5.3 \%)$ & 0.99 \\
\hline Smokers & $49(37.4 \%)$ & $21(37.5 \%)$ & $70(37.4 \%)$ & 0.99 \\
\hline Alcoholism & $18(13.7 \%)$ & $5(8.9 \%)$ & $23(12.3 \%)$ & 0.36 \\
\hline
\end{tabular}

VAI*: vaccinated against influenza in $1999 ; \mu=$ median

Table 2

Measured outcomes according with vaccination against influenza or not in 1999

\begin{tabular}{|c|c|c|c|c|c|}
\hline Variable & VAI* $131(70.1 \%)$ & Non-VAI $56(29.9 \%)$ & $\mathbf{n}$ & $\chi^{2}$ or $\mathbf{F}$ & $\mathbf{p}$ \\
\hline ILI** & $59(45 \%)$ & $27(48 \%)$ & $86(46 \%)$ & $\chi^{2}=0.16$ & 0.69 \\
\hline Times of ILI & $\mu=1.5$ & $\mu=2.25$ & & $\mathrm{~F}=5.7$ & $0.019^{\mathbb{\pi}}$ \\
\hline Use of antibiotics & $57(43.9 \%)$ & $24(29.6 \%)$ & $81(43.3 \%)$ & $\chi^{2}=0.007$ & 0.93 \\
\hline Use of antibiotics for respiratory disease & $25(19.1 \%)$ & $6(26.1 \%)$ & $31(38.8 \%)$ & $\chi^{2}=2.2$ & 0.14 \\
\hline Hospitalization & $25(19.1 \%)$ & $9(16.1 \%)$ & $34(18.2 \%)$ & $\chi^{2}=0.24$ & 0.62 \\
\hline Hospitalization for respiratory disease & $6(24.0 \%)$ & $1(11.1 \%)$ & $7(20.6 \%)$ & $\chi^{2}=0.67$ & 0.41 \\
\hline Times of treatments for respiratory disease & $\mu=1.20$ & $\mu=1.28$ & & $\mathrm{~F}=3.7$ & 0.061 \\
\hline
\end{tabular}

VAI*: vaccinated against influenza in 1999 ; ILI**: influenza like illness; $\mu=$ median; ${ }^{\pi}$ : p significant 
treatment of respiratory disease, hospitalization in general and for respiratory causes.

The accepted method to assess the severity of the influenza season is estimating the excess of pneumonia and influenza (P\&I) mortality. There is a linear correlation between excess of P\&I hospitalizations and mortality rates, in USA ${ }^{14}$. The effect of influenza in mortality varies in different countries. REICHERT et al. states the role of influenza in mortality in Japan is much greater than in United States ${ }^{12}$. This difference is probably associated with the environment and life style. It has been hypothesized that the efficacy of the vaccination is related to the match between the vaccine and the epidemic strains ${ }^{8}$. A study held in Argentina showed a partial match between the circulating influenza virus and the vaccinal strains, from 1994 to $1998^{13}$.

We found an association of previous vaccination against influenza with a reduction in the number of episodes of ILI, but not in other measured outcomes. The use of clinically defined ILI can account, at least partially, for the results.

The efficacy of the influenza vaccine is well established in elderly ${ }^{1}$. In a population of working healthy adults, the efficacy and costeffectiveness of the vaccination against influenza are still not established ${ }^{3}$.

The vaccines are more effective in reducing the laboratory confirmed cases of influenza than in the clinically defined cases ${ }^{5}$. Many cases of ILI, clinically defined, as we use as an outcome, may represent, in fact, infections caused by other agents. Laboratory-confirmed influenza represents just part of the clinically defined ILI.

Our study can be compared to that by NICHOL et al. ${ }^{10}$, which targeted elderly people living in the community. But, differently from that study, we did not find an association of influenza vaccination and reduction of hospitalizations for respiratory diseases. This difference may be attributed to the fact that in the study by NICHOL et al. the vaccine recipients reported a higher proportion of coexisting diseases than the non-vaccinated.

We did not find an association between the vaccination against influenza and the use of antibiotics for respiratory diseases, what makes our results different from that of CONNOLLY et al. ${ }^{4}$, who found, in a study from 1989, bronchitis and pneumonia the most frequent complications of influenza.

In Brazil the annual campaign of influenza vaccination, held since 1998 , is sponsored by the government. It provides free influenza vaccine for all persons 60 years or older, health care professionals and patients with chronic medical conditions, HIV infection and Aids. Since the influenza vaccination in Brazil has been available for large scale use for a few years, we can not compare our results with those found of HOSKINS et al. ${ }^{7}$, who suggested a decreased protection after a number of annual vaccinations. Besides, we do not have data on excess of mortality or hospitalization associated with influenza epidemics, before 1998 .

In Brazil the annual coverage of influenza vaccination in elderly is reducing, probably because large numbers of vaccinated did not perceive a reduction in the occurrence of influenza. Moreover misinformation attributes to the vaccine improbable side effects.
There is a need to raise the coverage of influenza immunization in elderly, since the vaccination is associated with a protective effect in this population. More studies are necessary to define the role of the vaccine in the protection of other groups in our country.

This is a retrospective study, based on information referent to the previous year, given by elderly subjects who may not have accurately remembered all possible influenza like illness episodes, what may have biased the results. Despite this facts, this study suggests that inactivated vaccine against influenza had a role in protection against influenza in elderly Brazilians.

\section{RESUMO}

\section{Efetividade da vacina contra influenza em população de idosos no município de São Paulo, Brasil}

Com o objetivo de investigar a efetividade da vacina contra Influenza em população de pacientes ambulatoriais, com 60 anos e mais, no Município de São Paulo, foram comparados retrospectivamente 187 pacientes dos quais 131 foram vacinados e 56 não foram vacinados contra influenza em 1999. Os dois grupos foram semelhantes com respeito às condições de saúde, características demográficas, tabagismo e alcoolismo. No ano posterior à vacinação, os vacinados apresentaram número de episódios clinicamente definidos como gripe, isto é, sem confirmação laboratorial, significativamente menor do que os não vacinados. Os outros parâmetros avaliados, a saber: ocorrência de gripe, de doença respiratória que não gripe, hospitalização por qualquer motivo e por doença respiratória, não diferiram nos dois grupos. Concluímos que a vacina contra influenza contribuiu para a redução do número de episódios caracterizados como gripe. São necessários mais estudos sobre a efetividade desta vacina em populações idosas e outros grupos populacionais brasileiros.

\section{REFERENCES}

1. AHMED, A.E.; NICHOLSON, K.G. \& NGUYEN-VAN-TAM, J.S. - Reduction in mortality associated with influenza vaccine during 1989-90 epidemic. Lancet, 346: 591-595, 1995.

2. BEYER, W.E.; de BRUIJN, I.A.; PALACHE, A.M.; WESTERNDORP, R.G. \& OSTERHAUS, A.D. - Protection against influenza after annually repeated vaccination: a meta-analysis of serologic and field studies. Arch. intern. Med., 159: 182-188, 1999.

3. BRIDGES, C.B.; THOMPSON, W.W.; MELTZER, M.I. et al. - Effectiveness and costbenefit of influenza vaccination of healthy working adults: a randomized controlled trial. J. Amer. med. Ass., 284: 1655-1663, 2000.

4. CONNOLLY, A.M.; SALMON, R.L.; LERVY, B. \& WILLIAMS, D.H. - What are the complications of influenza and can they be prevented? Experience from the 1989 epidemic of H3N2 influenza A in general practice. Brit. med. J., 306: 1452-1454, 1993.

5. DEMICHELI, V.; RIVETTI, D.; DEEKS, J.J. \& JEFFERSON, T.O. - Vaccines for preventing influenza in healthy adults (Cochrane review). In: The Cochrane Library, Issue 1. Oxford, Update Software, 2001.

6. GLEZEN, W.P. - Emerging infections: pandemic influenza. Epidem. Rev., 18: 64-76, 1996.

7. HOSKINS, T.W.; DAVIES, J.R.; SMITH, A.J.; MILLER, L.C. \& ALLCHIN, A. Assessment of inactivated influenza-A vaccine after three outbreaks of influenza A at Christ's Hospital. Lancet, 1: 33-35, 1979. 
8. KEITEL, W.A.; CATE, T.R.; COUCH, R.B.; HUGGINS, L.L. \& HESS, K.R. - Efficacy of repeated annual immunization with inactivated influenza virus vaccines over a five year period. Vaccine, 15: 1114-1122, 1997.

9. MURPHY, B.R. \& WEBSTER, R.G. - Orthomyxoviruses. In: FIELDS B.N.; KNIPE, D.M. \& HOWLEY, P.M., ed. Fields Virology. 3. ed. Philadelphia, Lippincott-Raven Publishers, 1996. p. 1397-1445.

10. NICHOL, K.L.; MARGOLIS, K.L.; WUOREMNA, J. \& STEMBERG, T.V. - The efficacy and cost-effectiveness of vaccination against influenza among elderly persons living in the community. New Engl. J. Med., 331: 778-784, 1994.

11. NICHOL, K. L.; WUORENMA, J. \& VON STERNBERG, T. - Benefits of influenza vaccination for low, intermediate and high-risk senior citizens. Arch. intern. Med., 158: 1769-1776, 1998.

12. REICHERT, T.A.; SUGAYA, N.; FEDSON, D.S. et al. - The Japanese experience with vaccinating schoolchildren against influenza. New Engl. J. Med., 344: 889-896, 2001.
13. SAVY, V.L.; BAUMEISTER, E.G. \& PONTORIERO, A.V. - Estudio antigenico de cepas de influenza (H3N2) circulantes en la Argentina y su relación con las cepas vacunales. Medicina (B. Aires), 59: 225-230, 1999.

14. SIMONSEN, L.; FUKUDA, K.; SCHONBERGER, L.B. \& COX, N.J. - The impact of influenza epidemics on hospitalizations. J. infect. Dis., 181: 831-837, 2000.

15. TREANOR, J. - Influenza virus. In: MANDELL, G.; MANDELL, G.L; BENNET, J.E \& DOLID, R., ed. Principles and practice in infectious diseases. 5. ed. Philadelphia, Churchill Livingstone, 2000. p. 1823-1849

16. VIGIGRIPE, 2(1, edição especial), fevereiro de 2001.

Received: 8 May 2001

Accepted: 3 October 2001 